\title{
How Poverty Engenders Irrational Economic Behavior: An Analysis of Psychological and Economic Behavior of Marginalized Communities
}

\author{
Neel Malhotra
}

\begin{abstract}
The psychological consequences of poverty are far-reaching - even constraining the economic choice patterns of these underserved communities. Through various interactions with these communities in Mumbai, I realized that it is the mindset of the inhabitants in these underserved communities, their ignorance towards health, which leads them to inefficiently allocate their limited amount of money and make short-sighted and risk-averse decisions which usually favor habitual behaviors than goal-oriented ones.

This research study attempts to analyze the economic choice patterns (their inefficient decision-making) of the marginalized communities to understand what deters them from availing facilities that improve their health, such as water purifiers.

This Research study primarily attempts to delve deeper into the following:

a) Lack of awareness for the importance of health in these marginalized communities.

b) The behavioural expenditure pattern of these families and their inefficient financial resources allocation.
\end{abstract}

A survey ${ }^{1}$ was conducted across 100 families across four different slum clusters to capture the data on the demographic profile with emphasis on women who are the decision makers of the families and are more concerned towards the well-being of the family, and the awareness about general health issues. Moreover, financial data and their expenditure pattern were collected under different arenas starting with income, rent, Food, education, medical expenses, transportation, entertainment, savings, etc. The findings were almost similar across families and the data revealed that there was no significant problem of awareness on health issues as well as education, but the lack of resources as well as the limited resources was the most constraining factor for doing investments that will protect their future health. The irrational economic behavior is a cause, or an effect of poverty does not get established and was only reasonably inferred in this case study - and needs more empirical studies on a larger sample. These families live by the day and any surplus or saving after meeting the necessities is spent on either demerit goods such as Alcohol and Cigarettes (by men) or entertainment and related stuff. This distorted economic behavior is the cause of the "Poverty trap". This Research study, thought limited to a small area as compared to the size of Mumbai, is representative of the general ideology of poverty-ridden households and is thus a microcosm of a larger case study that would entail analyzing the behavioral pattern of thousands and lakhs of households.

Index Terms-Economic Choice Patterns, Risk-averse decision-making, Behavioral Expenditure Pattern, Poverty Trap

Neel Malhotra, Grade 12, Singapore International School, Mumbai, India

Refer to Appendix for the Questionnaire

\section{HYPOTHESIS}

In these marginalized communities, there are several problems that act as an impediment to escaping the Poverty trap:

A. Lack of financial resources to make futuristic, wise investments.

B. Sub-optimal money allocation - Effect, rather than cause, of Poverty

C. Despite the general view of poor water quality, no steps are taken towards purification.

\section{RESEARCH METHODOLOGY}

The questionnaire ${ }^{2}$ was designed in such a way that it would have open-ended questions directed towards the awareness of their families and their behavior towards various consumption habits. At the same time, the questions were designed in such a way that data analysis using concrete data rather than varied data could be performed. The three-page survey was converted into Hindi and Marathi (the local language) so that the women could read and understand. The sensitive questions were kept open-ended and given ranges so that we could avoid the specifics which would severely affect their willingness to reveal the truth.

For Example, the income levels as well as the amount spent on liquor were two questions that these women even were hesitant to reveal. Local help was sought from the respective community for helping out in collecting data. There was little resistance from very few $(<10 \%)$ as they did not understand the relevance of such information gathering and its impact on their daily problems. Even though, they would have been the best source of information for understanding comprehensively the issues faced, but the inability to speak the local language and the urban look gave them the scare and the hesitation.

\section{DEMOGRAPHIC PROFILE OF THE RESPONDENTS}

The data was collected from a list of 100 respondents, chosen randomly across 4 slum clusters. Majority of the respondents were women and between the age of 30-45. The distribution is as below: 
Area distribution - Profile of respondents

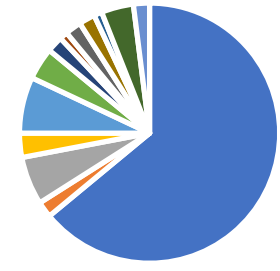

\begin{tabular}{|c|c|c|c|}
\hline $\begin{array}{l}\text { Goregaon } \\
\text { Jogeshwari } \\
\text { Thane }\end{array}$ & $\begin{array}{l}\text { Virar } \\
\text { Santacruz } \\
\text { - Mira Road }\end{array}$ & $\begin{array}{l}\text { Malad } \\
\text { - Kandivali } \\
\text { - Lower Parel }\end{array}$ & $\begin{array}{l}\text { Andheri } \\
\text { Bandra } \\
\text { - Nala Supara }\end{array}$ \\
\hline
\end{tabular}

Age Categories of Respondents

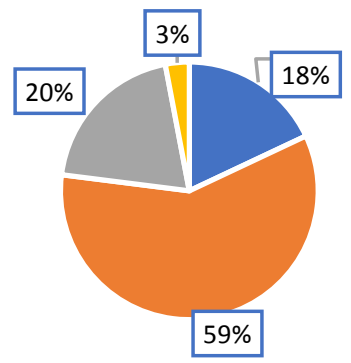

$=<30-30-45-45-60=>60$

Profession distribution - Respondents

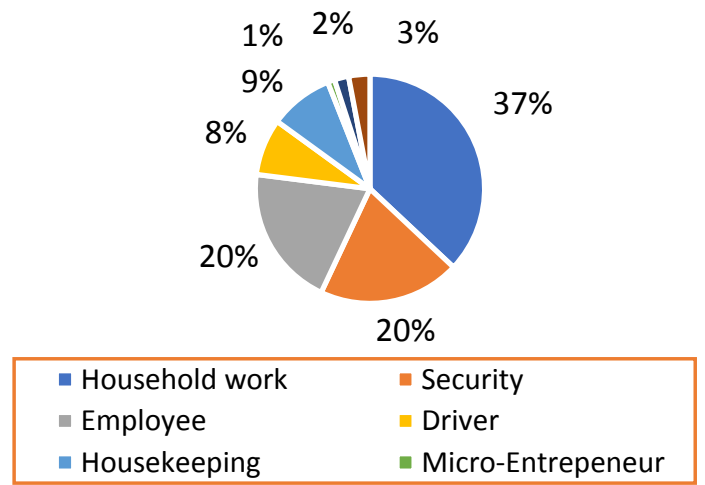

Income Profile of the Respondents

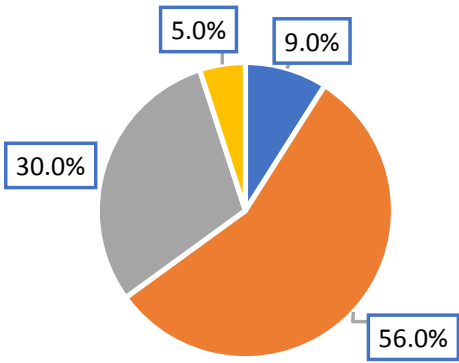

\begin{tabular}{|c|c|}
\hline - 0-10,000 & $-10,000-20,000$ \\
\hline $20,000-30,000$ & $=30,000$ \\
\hline
\end{tabular}

\section{CURRENT SITUATION}

Percentage of respondents who:

\begin{tabular}{|c|c|c|c|}
\hline $\begin{array}{l}\text { Source their water } \\
\text { from the municipal } \\
\text { authority (BMC) }\end{array}$ & $97 \%$ & $\begin{array}{l}\text { Have access to } \\
\text { drinking water } \\
\text { from source } \\
\text { all-day }\end{array}$ & $8 \%$ \\
\hline $\begin{array}{l}\text { Think that their } \\
\text { drinking water is } \\
\text { clean }\end{array}$ & $51 \%$ & $\begin{array}{l}\text { Have access to a } \\
\text { water purifier }\end{array}$ & $11 \%$ \\
\hline
\end{tabular}

\section{Method to Purify ${ }^{3}$}

Method to Store 4

- $69 \%$ of the respondents used a Steel Utensil to store drinking water.

- $36 \%$ of the respondents used a sand Pot to store drinking water.

- $29 \%$ of the respondents used a plastic drum/utensil to store drinking water.

\begin{tabular}{|l|l|l|l|l|l|l|}
\hline Boiling & $\begin{array}{l}\text { Plastic } \\
\text { Filter }\end{array}$ & Sieve & $\begin{array}{l}\text { Water } \\
\text { Purifier }\end{array}$ & Medicine & Others & $\begin{array}{l}\text { No } \\
\text { treatment }\end{array}$ \\
\hline $27 \%$ & $28 \%$ & $22 \%$ & $11 \%$ & $2 \%$ & $6 \%$ & $19 \%$ \\
\hline
\end{tabular}

Awareness of Water Purifiers and their benefits

Percentage of respondents who:

\begin{tabular}{|l|l|}
\hline $\begin{array}{l}\text { Were aware of } \\
\text { water purifiers? }\end{array}$ & $69 \%$ \\
\hline $\begin{array}{l}\text { Were aware of } \\
\text { the usability and } \\
\text { functions of a } \\
\text { water purifier? }\end{array}$ & $64 \%$ \\
& \\
\end{tabular}

\begin{tabular}{ll|l|}
\hline $\begin{array}{l}\text { Think that there are } \\
\text { benefits of a water } \\
\text { purifier? }\end{array}$ & $71 \%$ \\
\hline Out of those who & $96.6 \%$ \\
reported that there were & \\
no benefits of a water & \\
purifier, the percentage \\
of those respondents \\
that reported lack of \\
awareness as their \\
reason:
\end{tabular}

\begin{tabular}{|l|l|}
\hline $\begin{array}{l}\text { Reported that } \\
\text { water purifiers } \\
\text { make the water } \\
\text { clean }\end{array}$ & \\
& \\
\hline $\begin{array}{l}\text { Reported that } \\
\text { water purifiers } \\
\text { improve Health }\end{array}$ & \\
\hline
\end{tabular}

\begin{tabular}{|l|l|}
\hline $\begin{array}{l}\text { Reported that water } \\
\text { purifiers reduce the }\end{array}$ & $44 \%$ \\
incidence of sickness & \\
\end{tabular}

\footnotetext{
${ }^{3}$ There is intersection in the data - some respondents used more than one method to purify the water.

${ }^{4}$ There is intersection in the data-some respondents used more than one method to store the water.
} 
Status of quality of drinking water

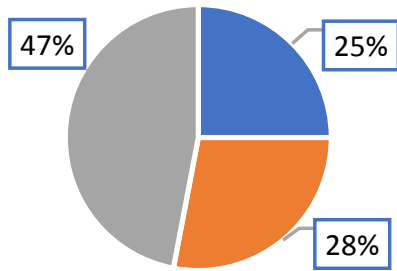

- Clean - Occasionally clean and dirty

A. Health and Awareness

Aware of the water-borne diseases caused by contaminated water?

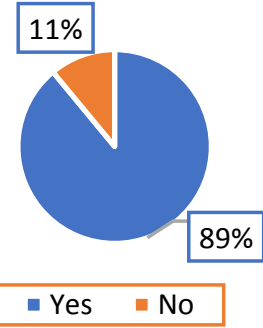

Frequency of doctor visits

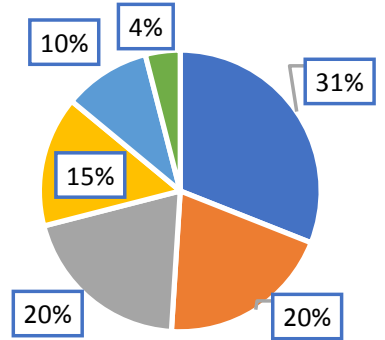

$\begin{array}{ll}- \text { More than once a month } & \approx \text { Once a month } \\ \square \text { Once in } 3 \text { months } & \\ - \text { Once in a year } & =\text { Once in } 6 \text { months } \\ & \end{array}$

B. Expenditure Pattern

Expenditure Pattern (Average expenditure for each recurring expense for 100 respondents)

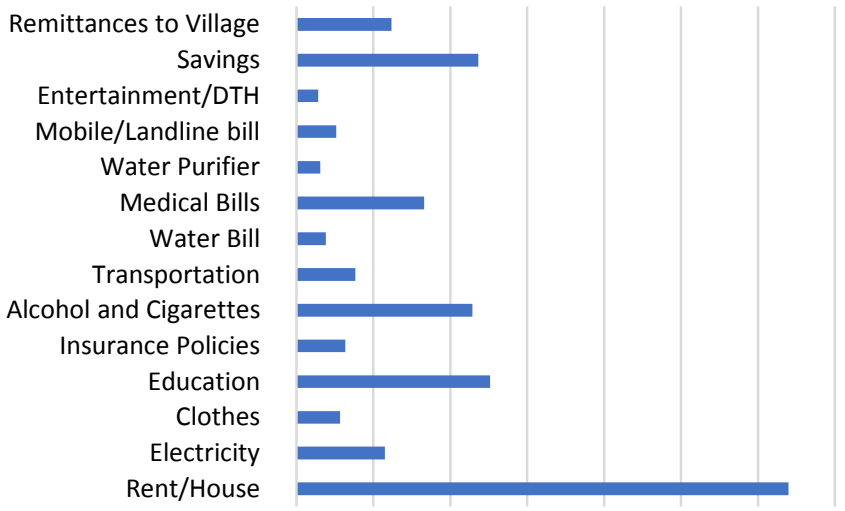

$1,0002,000 \quad 3,000 \quad 4,000 \quad 5,000 \quad 6,000 \quad 7,00$ Amount spent (Rs.)

\section{KEY OBSERVATIONS AND FINDINGS}

\section{A. Gender focused}

$64 \%$ of the respondents were men, and $36 \%$ were women. According to my observations, in most cases, the decision-maker of the families was the woman who worked outside as a maid/ employee/micro-entrepreneur and was more financially prudent. In certain cases, the men were not even interested, and the women were more comfortable in responding when the men were not present. $25 \%$ of the female respondents reported that they were the only income-earners of the family.

\section{B. Clean water relationship}

- $\quad 97 \%$ of the respondents reported that their source of drinking water is the BrihanMumbai Municipal Corporation (BMC).

- Out of the 100 respondents, only $8 \%$ of them reported that they got water all day. On average, the water is available for approximately 3 hours per day (in the mornings for some respondents, evenings for some, and alternate days for the rest).

- Method to Store and purify the water: Water is stored for daily consumption in potentially unclean utensils such as plastic drums, unwashed steel utensils, and sand pots. These methods to store the water could also potentially act as sources of contamination of water.

○ To purify the water, only $27 \%$ of the respondents use boiling as a way to purify water, and only $11 \%$ use Water Purifier machines. The rest rely on unreliable methods such as Plastic filters, sieve, Medicinal treatment, etc., with some (19\% of respondents $\left.{ }^{5}\right)$ not purifying the water using any methods.

- Awareness of water purifiers: $36 \%$ of the respondents had not heard of Water Purifiers and their functions before, and when they were briefed about it, their nature of response indicated that they were not very interested in availing these facilities.

- General Awareness about water cleanliness and quality: Ignorance was the key deterrent to solving this problem. Some did not know about how their water quality was, and $51 \%$ of the respondents think that their drinking water is sometimes clean.

- Water Purifiers have a major positive impact on the health of the respondents, as highlighted in the figures below:

\footnotetext{
${ }^{5}$ Supporting evidence for Hypothesis (c)
} 
Incidence of water-borne illnesses Respondents who DID NOT have a Water

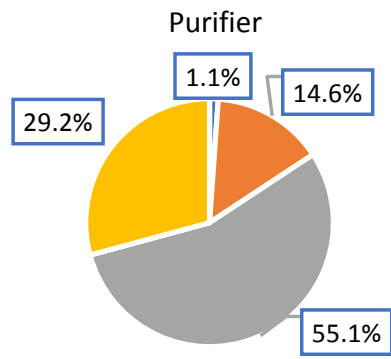

- Never $\approx$ Once a week $\approx$ Once a month $\|$ Once a year

Incidence of water-borne illnesses Respondents who possessed Water Purifiers

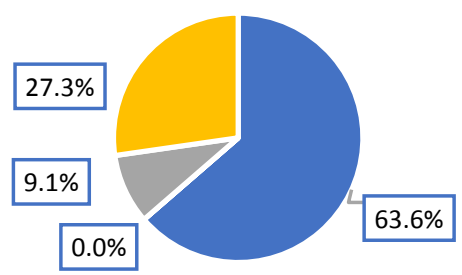

- Never $\backsim$ Once a week $\backsim$ Once a month $\approx$ Once a year

The clear difference in the frequency of water-borne illnesses of respondents due to unclean water between those who had water purifiers and those who did not have water purifiers is highlighted above. Those that did not have a water purifier suffered from water-borne illnesses such as fever, cough, and more severe diseases occasionally such as Diarrhea and Malaria relatively frequently (with $55.1 \%$ of them suffering from some water-borne illness every month). On the other hand, those who had water purifiers rarely suffered from such illnesses (with $63.6 \%$ of them never facing water-borne illnesses).

This clear difference can also be reflected in the difference in the medical bills (expenditure on health care) for both the types of respondents - those who did not have a purifier vs those who did, as highlighted below:

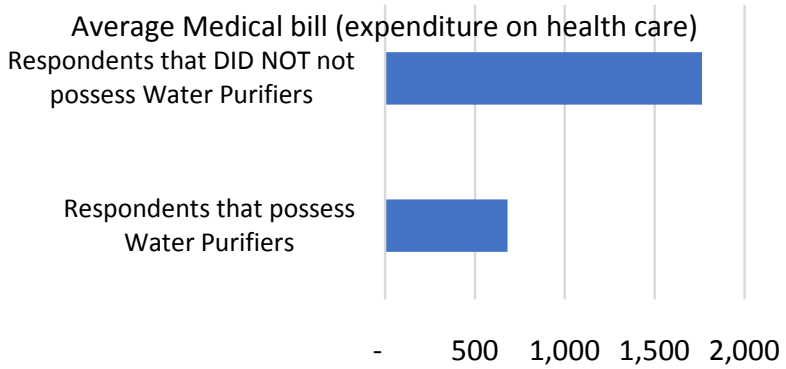

Those who did not have a water purifier tend to spend more for their medical bills.

- Infrastructural problems - Various interactions and visits to these communities made me realize that the infrastructural system was ill-equipped to provide clean water - Pipe break and dirt around the pipes were a major cause of water contamination.

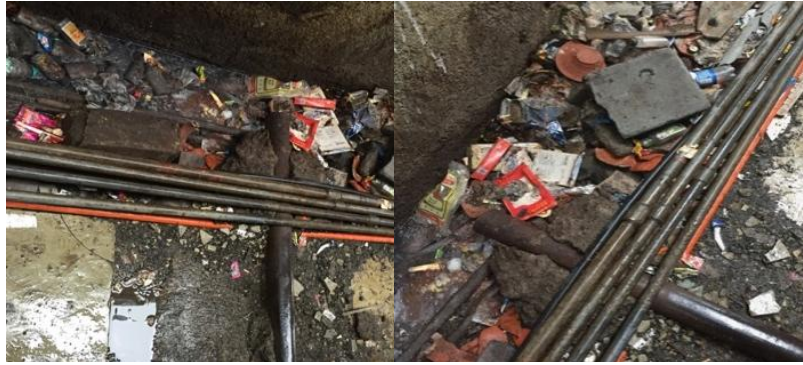

Pictures taken near a slum cluster in Goregaon East

\section{INSIGHTS INTO THESE COMMUNITIES}

The survey revealed interesting observations about the psychological behavior of the people stuck in the vicious poverty trap. The findings are enumerated below in detail:

a) Women- key driver of the household.

b) Sense of one-upmanship is there among the community members.

c) Men tend to be careless about most of the critical aspects of sustenance and well-being.

d) Focus on education is widespread despite the limited means.

e) Health is an important issue- but the active involvement in curbing diseases is lacking.

f) Expenditure towards entertainment, especially DTH (Television) is integral to their happiness and enjoyment in life, and in most cases, it even ranks above health and education in the priority list.

g) Liquor continues to be a menace and one of the root cause of all problems - can be called a cause and effect of these problems.

h) Water purifiers were not present and some families believe that the Municipal water supplied is clean despite various instances of yellowish water filled with insects (understood through my interactions with these communities).

A. General Psychology of the respondents (Social and Cultural influences governing their decision-making)

i. Most stuck in a vicious downward spiral- These communities are stuck in a vicious cycle which deters them from escaping the poverty trap. They have a feeling that it is next to impossible to come out in this generation. 


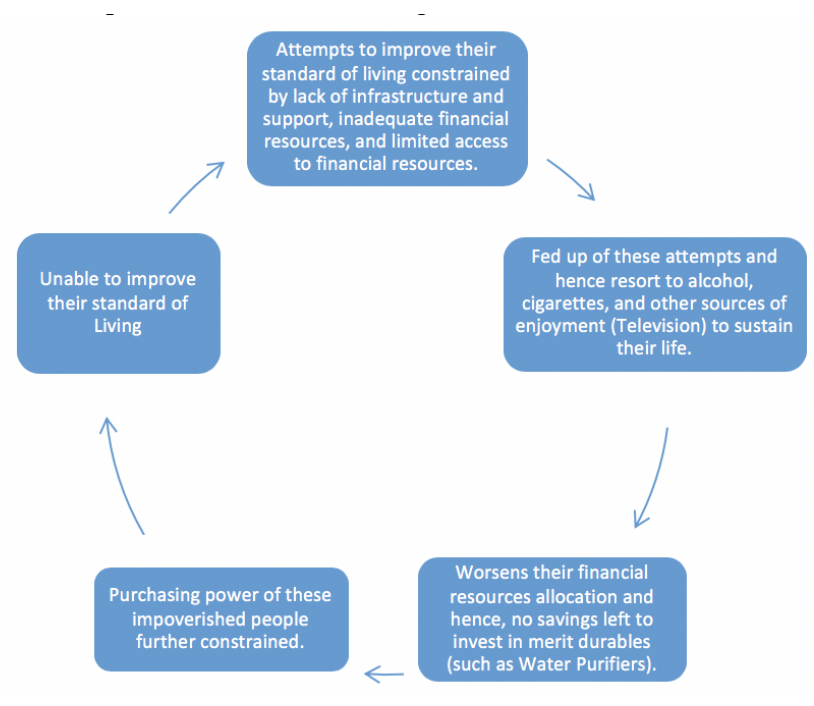

ii. Inefficient, sub-optimal money allocation and no financial literacy leading to constrained savings and thus no purchasing power available to spend on durable merit goods - for example purifiers.

iii. No futuristic investments are made - like insurance. $49 \%$ of the respondents never had Insurance of any form in their life! Hence, this vicious cycle does not allow them to change their attitudes even if they want to, as they have other more necessary ("jyadazaruat") expenses such as education, household expenses, fridge, etc., and leaves them with no money. Thus, this provides ample evidence of proving the Hypothesis (a).

iv. Money as Proxy for belief - No belief in the system of improving one's health - As in the data, the range for the willingness to pay a premium for clean water is indicative of their level of priority for health and well-being. When respondents were asked if they would pay a premium for clean water, $26 \%$ of them refused to pay a premium, citing reasons of either a 'useless' expense or lack of money to afford this facility.Money acts as a proxy for belief in many circumstances (which could be constrained by the scarcity of financial resources in cases of poverty-ridden communities), including this one.

Range for willingness to pay a premium for clean drinking water

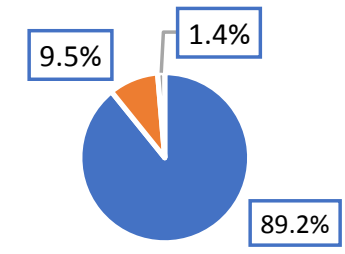

- $<1000=1000-2000 \quad \square>2000$
$89.2 \%$ of those that were willing to pay a premium were willing to incur a recurring expense of less than Rs. 1000 only. At the same time, most of those respondents spent more than Rs. 2000 every month on Alcohol and Cigarettes, thus revealing insights into their psychology of decision-making and their sub-optimal financial resources allocation.

In theory, governed by various schools of thought, every consumer wishes to maximize his/her own utility and satisfaction when consuming products. In this case, it seems that products like Alcohol and Cigarettes, as well as expenditure on television stood higher than merit goods like Water Purifiers in their priority list. The gap accounting for this inability of theory to reflect this decision-making is the lack of awareness of the positive health impact of Water Purifiers.

v. Health issues not relevant for them: "As nothing has happened to them before, nothing will happen now" (quoted by a respondent in Hindi). They are not aware of the fatal nature of water-borne diseases, and only those who have had past experiences of close relatives dying of water-related diseases are concerned and strongly feel to move away their thinking from this immature thought.

vi. Ignorance is the culprit: Most respondents were ignorant - "I don't care" kind of attitude - and don't pay enough attention on improving their health. Initially, there is hardly any savings in these households and hence not enough money to purchase merit goods such as purifiers, clean, hygienic water/food. The quantum of medical bills on a monthly basis is high and that further leads to no savings for the future -- the vicious cycle of poverty.

vii. Belief that the Government/Municipal Authority will solve all their problems: Some respondents were fed up of the deteriorating water quality - as reflected in the data of the current situation of quality of drinking water. $82 \%$ of the respondents believed that the Municipal Authority (BMC) had the onus of providing clean drinking water to them. This belief prevented them from taking any active steps to improve the quality of their water such as investing in a Water Purifier or boiling their water.

viii. Broken/Rusted Pipes and water Infrastructure - A major source of water contamination - Pipes were flowing through the sewage and close to trash collections, but, despite several complaints, the Municipal Authority has done nothing about it.

As a result, most are fed up of their efforts to improve their living and hence resort to alcohol and cigarettes to live their life - which worsens their position further. 


\section{B. Insights into their Economic choice patterns}

i. Decent Income levels but irrational expenditure patterns:This was the key takeaway for the group. In some instances, micro-entrepreneurs, drivers worked at several places during the day to generate avenues of income, and therefore constraint of financial resources was not present. These people generate a lot of cash on a daily basis (almost entirely tax free) but the expenditure on demerit goods as well as lack of financial prudence are the real causes of their persistence in poverty.

ii. Evaluating Hypothesis (b) - Irrational economic behaviour a cause or an effect of Poverty: My survey revealed that the irrational and financially imprudent economic behaviour was the cause of poverty. As mentioned above, most household incomes are above the severely low levels and thus can help them come out of the poverty 'syndrome', if they choose to channelize their savings in the optimal direction.

iii. Prioritize on education: This was the most significant finding of the survey. Everyone, especially the ladies in the house, focussed on education and wanted their kids to study, as this is a stepping stone to escape the vicious poverty trap. The fear of dropping out of school due to inadequate financial resources further empowered the community to generate avenues of income to support this expenditure.

iv. Inadequate spending on health: Health was least focussed and addressed only when they get sick. The unhygienic conditions are a big hurdle and nothing is done to improve the conditions and environment around them.

v. Liquor- a bigger menace, but a discretionary spend by the male members: Most alcohol and cigarettes consumed by husbands, and the women seem to detest this, both because of the frequency of consumption and the quantum of resources it consumes, as it also drains the energy to do daily work. It was also a root cause of the unemployment.

vi. Live by the day: They are all focussed towards fulfilling the daily expenses. There is no concept of savings and future investment on durable merit goods. They tend to focus on current expenses and current issues. They lack financial literacy to make futuristic decisions, and thus, this qualitative observation provides evidence to support Hypothesis (a). vii. Tendency to not plan for future - Financial planning was totally absent from their to-do list. The bank accounts, monthly saving schemes, and insurance for the future were yet-to-be availed services for most of the respondents' group.

viii. Key to all was Employment: Employment and stability of jobs were the most crucial aspects discussed in these communities. Most of the respondents did not have permanent full-time jobs and was a cause of misery for these communities.

Money or attitude: This was a trade-off that I identified based on my interaction with community members. They were caught in a quandary- is it their lack of financial resources or is it their lack of attitude that is not enabling them to escape the poverty trap. Escaping the poverty trap need both the drivers -- adequate money and a right approach. Money is a significant driver as it will enable them to spend on goods (increase their savings) which they couldn't before. Moreover, the right approach towards financial prudence will help them to invest appropriately in their future on education and merit goods such as water purifiers, etc. As per my discussions, some avoid doctor visits, even during diseases, because of the lack of money, and have no faith in government hospitals as they lack specialty, quality, and hospitality. Better finances through savings may be an answer to some of these problems.

More importantly, the most pressing issue is their attitude. They need to make financially efficient decisions, and can do so even with the amount of money they earn, and make rational decisions that maximise their own utility.

The importance of health is not recognized as expenditure on healthcare and well-being is lower on their priority list. Some respondents reported that "They don't get any time" (in hindi) to plan for their future or 'think' about health. Financial Literacy is a major step needed and the various schemes of the Government such as Financial inclusion through Microfinance Institutions is vital to revamping the mindsets and the current situation.

\section{EVALUATION AND CONCLUSIONS DRAWN FROM SURVEY DATA}

Primary data were collected personally through a structured and well-designed questionnaire (attached in the Appendix) from 100 households across various parts of Mumbai.

Correlation of water purifiers and health medical bills: The health medical bill was high but the willingness to take steps to prevent the diseases was lacking (as evidenced by my interactions with these communities). The respondents were hesitant to initiate steps to reduce contamination in the drinking water. Purifiers were seen as a big cost even though it was very low compared to their expenses on the DTH. Moreover, for my initiative (refer to makemywaterclean.com), I raised sponsorships through the 'Adopt a filter' campaign that helped to subsidize the cost of 
water purifiers up to $75 \%$ for these households. Despite significant decrease in the cost for these purifiers, they refused to spend on Water Purifiers. Moreover, information asymmetry could possibly exist in some sections of communities, and this lack of awareness might be the reason why merit goods like water purifiers are rare in these communities. These communities might have also evaluated the value added for the cost of a water purifier using a Cost-Benefit Analysis of water purifiers. And indeed, this might have highlighted the neglected value of a merit good, as evidenced by the definition of merit good under-consumed than what is socially optimal, if left to market forces.

Furthermore, Poverty causes stress and negative affective states which in turn may lead to short-sighted and risk-averse decision-making, possibly by limiting attention and favoring habitual behaviors at the expense of goal-directed ones. This Research Case Study substantiates this claim. Together, these relationships may constitute a feedback loop that contributes to the perpetuation of poverty.

Poverty may lower the willingness to take risks and to forgo current income in favor of higher future incomes. This may manifest itself in a low willingness to adopt new technologies and in low investments in long-term outcomes such as education and health, all of which may decrease future incomes.

\section{A. Inefficient allocation}

1. Out of those who think that their water is not clean, shockingly, only $6.12 \%$ of them possessed Water Purifiers.

2. On average, $14.4 \%$ of the respondent's income was spent for Alcohol and Cigarettes, whereas only 1.3\% of their income was spent on Water Purifiers.

\section{STUdy LIMITATIONS}

The survey responses were provided by women and in few cases the bread winner of the family. However, a key behavior was observed among the respondents:

Sense of shyness and urge to not always reveal the truth (especially the aspects that embarrass them or are extremely unusual.

Since the respondents were from a specific cluster, they feared that their financial details as well as health issues may get leaked or overheard by other community members and may lead to a negative effect on their 'image' in the society. Even though a sincere attempt was made to make them comfortable during the session and to ensure that the data will remain confidential, their expressions and reluctance to reveal insightful (and potentially embarrassing) information constrained the accuracy of my analysis of their mindsets.

\section{POLICY VIEWPOINTS}

I strongly feel that major policies implemented by the Government of India can be instrumental in alleviating some of these problems and empower these communities to escape the poverty trap. Policies such as the Financial Inclusion Scheme that empower these communities and transform their mindsets must be designed to maximize the welfare of the society. The social welfare schemes had a very limited impact on the lives of these people. A greater participation is required from both local and the central government in ensuring minimum necessities like sanitation and clean drinking water. The gap between their financial resources and their needs is a never-ending process and effective public policy should be geared towards bridging these gaps. According to my observations and insights gained through the interactions, several policy recommendations in terms of micro and macro level have been enumerated below:

\section{Micro-level}

District administration to conduct a study and under their mandate, it should identify the most pressing issues, in order of priority that impact the local community. The social projects need to be effectively taken up to improve the conditions of the local community. The process of approving and executing should be smoothened by possibly streamlining the entire process with the integration of technology.

NGOs are working in different areas. They need to pool in their resources and focus in these areas to address the most pressing issues. A focussed approach is the only way to resolve this.

\section{Macro-Level - Poverty Alleviation}

\#1 - Focus on Bottom-up approach - Currently, there is inadequate understanding of the problems faced by the marginalized communities. There needs to be a balance of bottom-up approach and the top-down approach to design the most-effective policies for the country. There is too much focus on top-down approach - trying to implement the best practices. A tribunal/body under the aegis of the Lok Sabha could be introduced that is specifically designed to address the problems of these underserved communities.

\#2 - As aforementioned, to resolve the plentiful problems faced due to piping infrastructure to provide uninterrupted access to clean drinking water, the state government must fund an investment in the water piping system to revamp the pipes which are a major source of contamination, especially lead and other metals.

\#3- Shift in approach from public expenditure for improving welfare (LPG Subsidies, etc) to empowering these communities (through microfinance, for example) to make their own decisions and improving welfare - not only give them access to these essential services, but also transform their mindset. This can be directly correlated with an increase in penetration of Microfinance and payment banks in these areas.

\#4 - Grievance redressal mechanisms for these marginalized communities - be able to voice their grievances and be heard in these communities - an important aspect of the bottom up approach.

\#5 Increasing awareness and penetration of Yojanas like Pradhan Mantri Suraksha Bima Yojana, Pradhan Mantri 
Jeevan Jyoti Bima Yojana, Pradhan Mantri Jan Dhan Yojana, Health insurance to provide stability and economic support in their lives, especially during bad times.

\#6 - A broader outlook to development - rather than implementing policies in favor of the 'rich' citizens (to gain political support), the government should implement those that aim for best practices, while addressing the concerns of as many communities as possible. The government could focus on a more 'progressive' outlook that aims to redistribute income and reduce the disparities in income.

Reflecting on the insights gained from this case study, it is certain that these policy recommendations can serve the needs of these underserved communities and be useful if implemented. 


\section{Appendix}

Survey - (makemywaterclean.com)
Area:

Date:

Introduction and Objective -: This is a project initiated by Neel Malhotra, student of Grade 12 in Singapore International School, Mumbai, to understand and analyse the behavioural pattern of people living in marginalized communities towards health and clean drinking water.

Demographic Profile

\begin{tabular}{|l|l|l|l|}
\hline Name: & Age: & \\
\hline Profession: & & Gender: & \\
\hline $\begin{array}{l}\text { Educational } \\
\text { Qualifications: }\end{array}$ & No. of Family Members: & \\
\hline $\begin{array}{l}\text { Number of } \\
\text { Earning } \\
\text { members: }\end{array}$ & & $\begin{array}{l}\text { Total number of } \\
\text { dependents: }\end{array}$ & \\
\hline $\begin{array}{l}\text { Number of } \\
\text { children under } 12 \\
\text { years old: }\end{array}$ & & $\begin{array}{l}\text { Number of Senior } \\
\text { Citizens (>60 yrs) : }\end{array}$ & \\
\hline
\end{tabular}

Screening Questions

"I am going to ask you about the drinking water that you get in your home. This is to understand the specifics of drinking water available in this area."

1) From where do you get your drinking water? (Source):

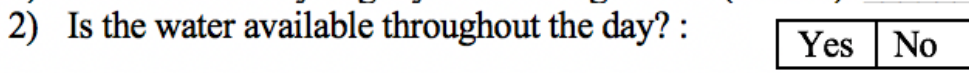

a. If NO, How many times do you get water during the day? :

b. If No, When the drinking water that you stored is over, where do you drink water from?

3) How do you store your water? : Pot/Jug/Bucket/ Any other:

4) Is the water used for drinking and for washing utensils/clothes etc. from the same source?:

5) What is the monthly water bill?:

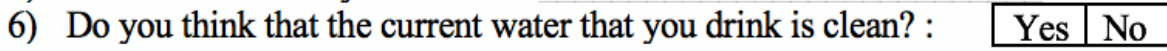

7) What is the method that you use to purify water for drinking?
a. If water purifier is NOT installed, Have you heard of any water purifier?

\begin{tabular}{|l|l|}
\hline Yes & No \\
\hline
\end{tabular}

8) Do you know what a water purifier is and what it can do?

9) What do you think is the cost of a water purifier?

\section{\begin{tabular}{|l|l|}
\hline Yes & No \\
\hline
\end{tabular}}

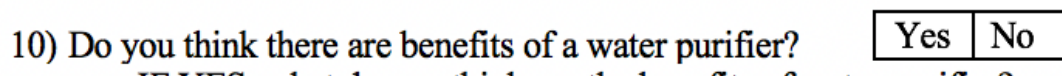

a. IF YES, what do you think are the benefits of water purifier?

b. IF NO, Why do you think there are no benefits?

11) If water purifier is not installed, Why didn't you buy a water purifier? 
How Poverty Engenders Irrational Economic Behavior: An Analysis of Psychological and Economic Behavior of Marginalized Communities

12) If the water purifier is installed, what is your experience? Do you think it has reduced your medical bills and incidence of sickness?

13) Is Clean water important to you? Yes

14) How frequently do you fall ill due to unclean water?

\begin{tabular}{|l|l|}
\hline Never & \\
\hline
\end{tabular}

\begin{tabular}{|l|l|}
\hline $\begin{array}{l}\text { Once a } \\
\text { week }\end{array}$ & \\
\hline
\end{tabular}

\begin{tabular}{|l|l|}
\hline Once a month & \\
\hline
\end{tabular}

Once a year

15) According to you, Whose responsibility is it to supply clean drinking water to you?:

16) Are you aware of the water-borne diseases caused by contaminated water?

\begin{tabular}{|l|l|}
\hline Yes & No \\
\hline
\end{tabular}

17) Are you willing to pay a premium for clean water?

\begin{tabular}{|l|l|}
\hline Yes & No \\
\hline
\end{tabular}

IF YES, how much more than your current bill?

18) Any general comments about "What you feel about your drinking water"?

\section{Health Awareness}

1) How many times do you visit a doctor, on average, in a week/month? :

\begin{tabular}{|l|l|}
\hline $\begin{array}{l}\text { More than once a } \\
\text { month }\end{array}$ & \\
\hline Once in 3 months & \\
\hline Once in a year & \\
\hline
\end{tabular}

\begin{tabular}{|l|l|}
\hline Once a month & \\
\hline Once in 6 months & \\
\hline More than once a year & \\
\hline
\end{tabular}

2) What is the monthly expenditure on medical health care? :

3) Do you go to a private Doctor or the government hospital ?:

\begin{tabular}{|l|l|}
\hline Private Doctor & \\
\hline Govt. hospital & \\
\hline Both & \\
\hline
\end{tabular}

\section{Financial Literacy:}

Do you have a bank account?:

Do you own a vehicle/bike?:

Have you heard of Micro Finance?:

\begin{tabular}{|c|l|}
\hline Yes & No \\
\hline Yes & No \\
\hline Yes & No \\
\hline
\end{tabular}




\section{Expenditure Pattern:}

In one month, approximately how much do you spend on:

\begin{tabular}{|l|l|}
\hline Rent/House & \\
\hline Electricity & \\
\hline Clothes & \\
\hline Education & \\
\hline Refrigerator & \\
\hline Insurance Policies & \\
\hline $\begin{array}{l}\text { Alcohol and } \\
\text { Cigarettes }\end{array}$ & \\
\hline
\end{tabular}

\begin{tabular}{|l|l|}
\hline Transportation & \\
\hline Water Bill & \\
\hline Medical Bills & \\
\hline Water Purifier & \\
\hline Mobile/Landline Bill & \\
\hline Entertainment/DTH & \\
\hline Savings & \\
\hline
\end{tabular}

Do you send money to village/family members? :

\begin{tabular}{|l|l|}
\hline Yes & No \\
\hline
\end{tabular}

IF YES, How much on average in a month?

What is the total average monthly household income?:

\begin{tabular}{|l|l|}
\hline $0-10,000$ & \\
\hline $20,000-30,000$ & \\
\hline
\end{tabular}

\begin{tabular}{|l|l|}
\hline $10,000-20,000$ & \\
\hline$>30,000$ & \\
\hline
\end{tabular}

Please note that no information will be shared across any platform. This information will only be used to analyse the expenditure patterns of different households.

Thank you! 


\section{ACKNOWLEDGMENTS}

I would like to thank my mentor, Mr. Pawan Kumar Sachdeva, for the patient guidance, encouragement and advice that he has provided throughout my research study. His invaluable guidance has been instrumental in designing the research process and successful completion of my research. His expertise in the field of water and his exemplary passion in this field has helped me to perform this Research study effectively and in a structured manner. My numerous interactions have helped me to improve my research capabilities and develop higher-order thinking skills. Even during the times when we would disagree on how to perform the study, these differences in opinion have only made this study more insightful and interesting.

I would also like to sincerely thank Mr. SumitKhatter, VP Communications at Tetra Pak, who helped me to design my questionnaire for the targeted audience using his experience and shared key insights into the dynamics of these communities in order to ensure that the data collection process was as smooth and insightful as possible. Finally, I must express my gratitude to my younger brother, Gaurav, who has provided constant support and encouraged me to conduct the research in all weather conditions, especially during the heavy monsoon in July and August, when my study was conducted.

\section{REFERENCES}

[1] Edna , Sawady R., and Jennifer Tescher. Financial Decision Making Processes of Low-Income Individuals. UCC08-2. February 2008

[2] Thoma, Mark. "Economist's View." Economist's View: Is Poverty Caused by Irrational Behavior?, 30 Mar. 2008, 3:03 AM, economistsview.typepad.com/economistsview/2008/03/is-poverty-cau s.html.

[3] Spears, Dean. "Economic Decision-Making in Poverty Depletes Behavioral Control." The B.E. Journal of Economic Analysis \& Policy, De Gruyter, 1 Apr. 2013, www.degruyter.com/view/j/bejeap.2011.11.issue-1/1935-1682.2973/1 935-1682.2973.xml

[4] Vissing-Jorgensen, Annette. "Perspectives on Behavioral Finance: Does 'Irrationality' Disappear with Wealth? Evidence from Expectations and Actions." NBER Macroeconomics Annual, vol. 18, 2003, pp. 139-194., doi:10.1086/ma.18.3585252.

[5] Maréchal, Kevin. "Not Irrational but Habitual: The Importance of 'Behavioural Lock-in' in Energy Consumption." ScienceDirect, Academic Press, 12 Jan. 2010, www.sciencedirect.com/science/article/pii/S0921800909005059.

[6] Cummings, Jon, et al. "Irrational Consumption: How Consumers Really Make Decisions." McKinsey \& Company, www.mckinsey.com/business-functions/marketing-and-sales/our-insi ghts/irrational-consumption-how-consumers-really-make-decisions.

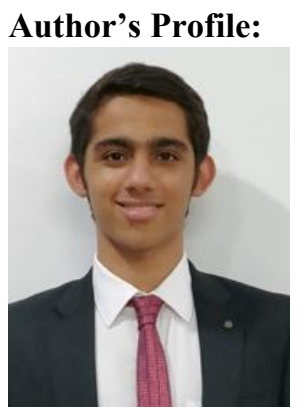

Neel Malhotra, a student of Grade 12 (IBDP) at Singapore International School, Mumbai, has actively pursued his academic interests, which range from Economics, particularly Welfare and Behavioral Economics, and public policies and analysis to using mathematical tools to analyze data. Moreover, he has strived to leverage this knack in Economics and public policies to delve deeper into the dynamics of the marginalized communities, as captured by this research study. To further on this interest, he has also conducted an independent research study to assess the sustainability of Microfinance Institutions in India through statistical tools and analysis. Not only has he understood the driving forces in these communities, he has also attempted to tackle these problems in an attempt to give back to society - primarily characterized by his social outreach project - makemywaterclean.com - to provide clean drinking water to marginalized communities in Mumbai. To further enhance his research capacity, he has also conducted a research study on the Drinking Water quality in Mumbai by associating with a laboratory, and accordingly compiled policy recommendations for the Bombay Municipal Corporation.

He has also been involved in various other activities outside the classroom and has taken various leadership roles in his School. He is a Student Council Representative and has ideated and initiated the idea of hosting a TEDx Youth event in his school - being the Licensee and Curator of the first-ever TEDx Youth conference hosted in his school. 